\title{
Tantangan Guru Pendidikan Agama Islam Pada Sekolah Inklusi di Yogyakarta
}

\author{
1Sutipyo Ru'iya, 2Fandi Akhmad, 3Diana Putwiyani, ${ }^{4}$ Anjar Sulistiawan \\ 1234 Prodi Pendidikan Agama Islam Universitas Ahmad Dahlan \\ 1s sutipyo@pai.uad.ac.id,2fandi.akhmad@pai.uad.ac.id,3dianapuput73@gmail.com. \\ 4anjarsulistiawan@gmail.com
}

\begin{abstract}
Abstrak: Semakin berkembangnya sekolah inklusi secara kuantitas di Yogyakarta, ternyata belum diikuti perkembangan secara kualitas. Beberapa sekolah inklusi berjalan hanya sekedar jalan secara operasional, tanpa memperhatikan santar pelayanan. Penelitian ini berupaya mengungkap tantangan guru Pendidikan Agama Islam yang mengajar di sekolah inklusi, karena sebagian besar guru Pendidikan Agama Islamtidak mempunyai latar belakang pendidikan inklusi. Penelitian ini meneliti di dua sekolah inklusi dengan sumber data guru Pendidikan Agama Islam di sekolah A sebanyak dua orang dan sekolah B sebanyak tiga orang. Data dikumpulkan melalui wawancara mendalam kepada semua guru Pendidikan Agama Islam dan kepada guru pembimbing khusus. Data yang diperoleh di analisis melalui tahapan reduksi data, penyajian data secara terpola, dan pengambilan kesimpulan. Hasil penelitian di peroleh bahwa tantangan guru Pendidikan Agama Islam dalam menjalankan tugas secara garis besar dibagi menjadi tiga yaitu: tidak mempunyai kompetensi tentang anak berkebutuhan khusus, sulit memahami karakteristik anak berkebutuhan khusus, dan melakukan kerjasama dengan guru pembimbing khusus bagi yang punya dan melakukan pendalaman dan pengkajian anak berkebutuhan khususmelalui buku-buku.
\end{abstract}

Kata Kunci: Anak Berkebutuhan Khusus, Guru Pembimbing Khusus, Inklusi.

\begin{abstract}
The increasing quantity of inclusive schools in Yogyakarta has not been followed by developments in quality. Some inclusive schools run only as a road operationally, without paying attention to the delivery of services. This study seeks to reveal the challenges of Islamic Religious Education teachers who teach in inclusive schools, because most Islamic Religious Education teachers do not have a background in inclusive education. This study examined two inclusion schools with data sources of Islamic Religious Education teachers in school A as many as two people and school B as many as three people. Data were collected through in-depth interviews with all Islamic Religious Education teachers and to special supervisors. The data obtained were analyzed through the stages of data reduction, patterned data presentation, and drawing conclusions. The results of the research show that the challenges of Islamic Religious Education teachers in carrying out their duties are broadly divided into three, namely: not having competence about children with special needs, difficulty understanding the characteristics of children with special needs, and collaborating with special guidance teachers for those who have and deepen and assessment of children with special needs through books.
\end{abstract}

Keywords: Children With Special Needs, Special Guidance Teachers, Inclusion

\section{PENDAHULUAN}

Perhatian pemerintah Indonesia terhadap pendidikan warga negara semakin tinggi. Hal ini dapat dilihat pada beberapa bebreapa indikator diantaranya bahwa pada beberapa tahun terakhir jumlah anggaran pendidikan pada Anggaran 
Pendapatan dan Belanja Negera (APBN) semakin meningkat. Selain persiapan anggaran dalam APBN yang ditingkatkan, pemerintah juga telah menyiapkan dari unsur undang-undang yang semakin lengkap.

Pemerintah juga berupaya agar pendidikan harus merata dan dapat dinikmati oleh semua warga pada usia sekolah tanpa terkecuali. Pemerintah telah menetapkan Undang-Undang No. 20 Tahun 2003 tentang Sistem Pendidikan Nasional, yang pada pasal 5 disebutkan bahwa: "Setiap warga negara mempunyai hak yang sama untuk mengeyam pendidikan, dan warga Negara yang memiliki kelainan fisik, emosional, intelektual, mental dan/atau sosial berhak memperoleh pendidikan khusus." Undangundang tersebut berdampak pada penyelenggaran pembelajaran anak berkebutuhan khusus dilaksanakan secara tersendiri di Sekolah Luar Biasa (SLB).

Anak difabel (anak berkebutuhan khusus/ABK) disediakan fasilitas tersendiri dalam pendidikan secara khusus yang diselaraskan dengan jenis dan derajat kekhsusannya. Sistem pendidikan khusus anak berkebutuhan khusus ini secara tidak disadari telah membangun tembok eksklusifisme bagi ABK. Eksklusifisme yang menjadi tembok penghalang selama ini oleh masyarakat tidak disadari telah menghalangi proses saling berinteraksi antara anak-anak berkebutuhan khusus dengan anak-anak normal. Dampaknya dalam interaksi sesama di kingkungan masyarakat kelompok anak berkebutuhan khusus menjadi kelompok yang terpinggirkan dari dinamika kehidupan. Masyarakat menjadi asing dengan kehidupan komunitas anak berkebutuhan khusus. Sementara komunitas anak berkebutuhan khusus sendiri merasa keberadaannya terpinggirkan seolah tidak menjadi bagian yang menyatu dengan kehidupan masyarakat di sekelilingnya. ${ }^{1}$

Realitas di atas apabila tidak dirubah akan berlangsung terus menerus entah sampai kapan berakhir. Anak-anak berkebutuhan khusus (ABK) akan selalu dipandang rendah, tidak dianggap penting. ABK akan tersingkir dalam dalam stu kelompok masyarakat tertentu. Sementara pada anak ABK sendiri akan menjadi semakin introvert, karena menganggap bahwa keberadaannya tidak menjadi integral dengan kehidupan diekitarnya. ${ }^{2}$ Padahal anak-anak ABK adalah anak-anak Indonesia yang mempunyai hak yang sama dengan anak normal sebagaimana telah diamanatkan oleh UUD 1945 pada pasal 31 dan pasal 34. Melalui program dan pengelolaan pendidikan yang baik oleh pemerintah dan masyarakat, maka anak-anak ABK akan dapat berkarya, bermanfaat hidupnya dan berkembang sesuai dengan keadaannya

1 Sabaruddin Yunis Bangun, "Pengembangan Pengetahuan Anak Difabel Melalui Pendidikan Jasmani Olahraga dan Outbound," Journal Physical Education, Health and Recreation 1, no. 1 (October 16, 2016): 70-77, https://doi.org/10.24114/pjkr.v1i1.4777.

2 N. Praptiningrum, "Fenomena Penyelenggaraan Pendidikan Inklusif Bagi Anak Berkebutuhan Khusus," Jurnal Pendidikan Khusus 7, no. 1 (2010): 32-38. 
untuk maju, dan berkontribusi sebagaimana anak-anak normal untuk bangsa Indonesia dan dunia.

Untuk memberi pelayanan pendidikan yang optimal kepada $A B K$, pemerintah merespon dengan digalakkannya pendidikan inklusif. Perubahan pandangan dari pendidikan ekslusi manjadi pendidikan Inklusi, merupakan fenomena menarik di Indonesia. Di Indonesia pendidikan inklusi merupakan hasil dorongan konvensi internasional Education for All (EFA) dan kesepakatan deklarasi The Dakar Framework for Action. ${ }^{3}$ Selain itu juga telah terjadi kesepakatan internasional sistem pendidikan inklusif Conventional on the Right of The Person with Disabilities and Optional Protokol tahun 2007.4 EFA menyatakan bahwa Pendidikan harus dapat dinikmati oleh orang normal maupun orang berkebutuhan khusus. Semua hasil konvensi internasional tersebut menyatakan bahwa setiap negara wajib menyenggarakan sistem pendidikan inklusif pada setiap jenjang pendidikan.

Pemerintah Indonesia berusaha merespon semua hasil konvensi internasional tersebut dengan Peraturan Menteri Pendidikan Nasional No 70 tahun 2009 tentang pelaksanaan pendidikan inklusi. Untuk memperkuat program ini, maka Pemerintah Indonesia menurunkan Peraturan Pemerintah Nomer 19 tahun 2015. Pada pasal 41 ayat (1) PP Nomer 19 amanahkan agar Setiap satuan pendidikan yang menyelenggarakan proses pendidikan inklusif agar mempunyai tenaga kependidikan yang memiliki kompetensi untuk melaksanakan proses pendidikan bagi siswa-siswa yang kebutuhan khusus. ${ }^{5}$

Program peningkatan jumlah sekolah inklusi menjadi program yang massif, sehingga setiap daerah seolah-olah "berlomba" untuk menetapkan sekolah-sekolah umum menjadi sekolah inklusi. Di Provinsi Yogyakarta telah ditetapkan 239 sekolah inklusi oleh pemerintah, mulai dari jenjang sekolah dasar sampai sekolah menengah atas. $^{6}$

Meningkatnya jumlah sekolah inklusi belum diimbangi dengan peningkatan kualitas layanan terhadap ABK terutama penyediaan fasilitas dan tenaga pendidikan yang profesonal. Tarnoto menyatakan pada hasil penelitiannya bahwa masih banyak hal yang harus dibenahi pada sekolah inklusi, terutama tentang kemampuan tenaga

\footnotetext{
${ }^{3}$ Reno Fernandes, "Adaptasi Sekolah Terhadap Kebijakan Pendidikan Inklusif," SOCIUS 4, no. 2 (March 12, 2018): 119-25, https://doi.org/10.24036/scs.v4i2.16. Khusus."

4 Praptiningrum, "Fenomena Penyelenggaraan Pendidikan Inklusif Bagi Anak Berkebutuhan

${ }^{5}$ Nurul Kusuma Dewi, "Manfaat program pendidikan inklusi untuk AUD," Jurnal Pendidikan Anak 6, no. 1 (2017): 12-19.

6 Nissa Tarnoto, "Permasalahan-permasalahan yang dihadapi sekolah penyelenggara pendidikan inklusi pada tingkat SD," HUMANITAS 13, no. 1 (July 19, 2016): 50-61, https://doi.org/10.26555/humanitas.v13i1.3843.
} 
pendidiknya. Hal yang sama disampaikan oleh Ery Wati dalam implementasinya banyak sekolah inklusi yang tidak sesuai dengan konsep ideal yang mendasar. ${ }^{7}$ Tias $^{2}$ Martika Anggriana menyebutkan bahwa guru didalam mendampingi/mengajar anak ABK diharapkan memiliki beberapa kompetensi, diantaranya: dapat menerima semua siswa dengan kekhususannya masng-masing, melaksanakan kurikulum yang fleksibel dan akomodatif, merancang kegiatan belajar mengajar (KBM) yang ramah anak, dan dapat memanfaatkan media yang adaptif. 8

Berbagai macam kompetensi guru pada sekolah inklusi ini menjadi tantangan tersendiri kepada guru-guru di sekolah tersebut, termasuk juga guru Pendidikan Agama Islam. Latar belakang inilah yang memotivasi peneliti untuk mengetahui lebih mendalam tentang tantangan guru Pendidikan Agama Islam pada sekolah inklusi di Yogyakarta.

Dari latar belakang yang telah disampaikan pada bagian sebelumnya, maka dapat dirumuskan dua masalah pada penelitian ini yaitu: pertama, apa saja tantangan yang dihadapi oleh guru Pendidikan agama dalam melaksanakan tugasnya di sekolah inklusi? Dan kedua, bagaimana para guru Pendidikan Agama Islam menghadapi berbagai macam tantangan di sekolah inklusi tersebut?

Penelitian ini sangat penting, karena guru merupakan ujung tombak pada proses penyelenggaraan pendidikan. Pendidikan inklusi merupakan pendidikan yang berciri khusus, dengan kriteria tertentu. Guru yang berkecimpung pada sekolah inklusi, juga harus mempunyai pengetahuan tentang keilmklusian tersebut. Guru harus menguasai kompetensi yang butuhkan dalam pelaksanaan profesinya, agar mendapatkan hasil yang yang sesuai dengan keinginan yang diharapkan. Sementara ini sejauh pengatahuan penulis belum ada pendidikan khusus bagi guru Pendidikan Agama Islam (PAI) untuk menangani anak-anak berkebutuhan khusus. Sementara itu, sekolah inklusi sudah berjalan beberapa tahun, sehingga perlu ada evaluasi atau penelitian di lapangan tentang hambatan apa saja yang dialami guru PAI dalam melaksanakan tugasnya.

\section{Pembelajaran Pendidikan Agama Islam di Sekolah Inklusi}

\section{Pendidikan Inklusi}

a. Definisi pendidikan inklusi

Pendidikan inklusi merupakan lembaga pendidikan yang mengadobsi

7 Ery Wati, "Manajemen pendidikan inklusi di Sekolah Dasar Negeri 32 Kota Banda Aceh," Jurnal Ilmiah Didaktika 14, no. 2 (February 1, 2014): 368-78, https://doi.org/10.22373/jid.v14i2.508.

8 Tyas Martika Anggriana and Rischa Pramudia Trisnani, "Kompetensi guru pendamping siswa ABK di sekolah dasar," JURNAL KONSELING GUSJIGANG 2, no. 2 (September 20, 2016): 157-64, https://doi.org/10.24176/jkg.v2i2.702. 
anak berkebutuhan khusus dan anak non berkebutuhan khusus. Pendidikan inklusi adalah sistem pendidikan mengakomodasi ABK untuk bersekolah dengan non-ABK pada kelas yang sama. ${ }^{9}$

Sekolah inklusi adalah suatu satuan pendidikan yang bersifat formal atau yang disebut sekolah reguler dimana sekolah tersebut menyelenggarakan pendidikan yang menyertakan anak berkebutuhan khusus (ABK) dan/atau mepunyai hambatan untuk memperoleh akses pendidikan yang bermutu seperti pada peserta didik lain pada umumnya. ${ }^{10}$ Muhammad Takdir Ilahi mengatakan bahwa sekolah inklusi adalah sekolah yang bersifat regular dalam satu kesatuan yang sistemik, namun kemudian diselaraskan dengan kebutuhan anak, yaitu terutama anak yang mempunyai kelainan atau anak yang memiliki potensi kecerdasan dan bakat istimew. ${ }^{11}$ Dari beberapa definisi di atas naka dapat disimpulkan yang dimaksud dengan sekolah inklusi adalah sekolah reguler yang mengadobsi dan menerima serta melakukan pembelajaran bagi anak ABK bersama dengan anak non ABK.

b. Karakteristik peserta didik di sekolah inklusi

Melihat dari definisi sekolah inklusi di atas maka peserta didik di sekolah inklusi terdiri dari anak berkebutuhan khusus dan anak non berkebutuhan khusus. Anak non berkebutuhan khusus adalah anak normal pada aspek psikologis dan aspek non psikologis/fisik. Sedangkan anak berkebutuhan khusus mempunyai kekhususan baik pada psikologis maupun fisik. Anak berkebutuhan khusus (ABK) sering disebut juga anak luar biasa. Dalam Psikologi Anak Luar Biasa, Sutjihati Somentari membagi anak luar biasa menjadi:

1) Anak tuna netra, yaitu anak yang mempunyai gangguan pada aspek penglihatan

2) Anak tuna rungu, yaitu anak mempunyai gangguan pada aspek pendengaran

3) Anak tuna daksa, yaitu anak mempunyai gangguan pada aspek fisik

4) Anak tuna laras, yaitu anak yang mempunyai gangguan emosi sehingga terjadi gangguan perilaku (behavioral disorder).

${ }^{9}$ Hasan Baharun and Robiatul Awwaliyah, "Pendidikan inklusi bagi anak berkebutuhan khusus dalam perspektif epistemologi Islam," MODELING: Jurnal Program Studi PGMI 5, no. 1 (March 2018): 57-71.

10 Dieni Laylatul Zakia, "Guru pembimbing khusus (GPK): Pilar pendidikan inklusi," Prosiding Seminar Nasional Pendidikan, November 21, 2015, 110-16.

11 Jamilah Candra Pratiwi, "Sekolah inklusi untuk anak berkebutuhan khusus: Tanggapan terhadap tantangan kedepannya," Prosiding Seminar Nasional Pendidikan, November 21, 2015, 237-42. 
5) Anak tuna grahita/mental retarded, yaitu mempunyai kemampuan intelektual di bawah rata-rata.

6) Anak berkrsulitan belajar, yaitu anak yang mempunyai beberapa gangguan seperti gangguan perseptual, konseptual, memory, maupun ekspresif dalam belajar.

7) Anak berbakat, yaitu anak yang mempunyai kemempuan intelektual di atas anak-anak normal. ${ }^{12}$

c. Model pendidikan inklusi di Indonesia

Model pendidikan inklusi yang dikenal dan diterapkan di Indonesia menurut Ashman dalam Ernawati (2008):

1) Kelas Reguler (Inklusi Penuh). Model pendidikan inklusi ini adalah ABK bersama dengan anak normal atau non ABK belajar di dalam kelas yang sama (reguler) sepanjang hari. Kedua karakter anak yang berbeda ini belajar dengan menerapkan kurikulum yang persis sama.

2) Kelas Reguler dengan Cluster. Model pendidikan inklusi ini adalah ABK bersama dengan anak normal atau non ABK, namun dibentuk modelmodel pembelajaran dalam kelompok khusus.

3) Kelas Reguler dengan Pull Out. Model pendidikan inklusi ini adalah ABK bersama dengan anak normal atau non ABK, namun hanya pada waktuwaktu tertentu. Pada waktu-waktu yang lain anak ABK dilakukan pembelajran dalam ruang lain untuk melakukan proses belajar yang dilakukan oleh guru pembimbing khusus.

4) Kelas Reguler dengan Cluster dan Pull Out. Model pendidikan inklusi ini adalah ABK bersama dengan anak normal atau non ABK di kelas reguler namun mereka belajar dalam kelompok tertentu (khusus). Pada waktuwaktu tertentu ABK tetap di kelas reguler, namun jika ada masalah khusus yang tidak dapat diselesaikan oleh guru mata pelajaran anak ABK belajar secara mandiri bersama dengan guru pembimbing khusus.

5) Kelas Khusus dengan Berbagai Pengintegrasian. Model pendidikan inklusi ini adalah ABK melakukan proses pembelajaran di kelas tersendiri. Namun pada waktu tertentu, ABK bersama dengan anak normal atau non ABK belajar dikelas reguler hanya untuk bidang-bidang tertentu.

6) Kelas Khusus Penuh. Model pendidikan inklusi ini adalah ABK belajar pada kelas tersendiri secara khusus. Sementara anak normal atau non

12 T. Sutjihati Somantri, Psikologi Anak Luar Biasa (Jakarta: Refika Aditama, 2012). 
ABK belajar di kelas tersendiri bersama anak normal yang lain. Namun kedua karakteristik anak ini belajar dalam sekolah yang sama. ${ }^{13}$

d. Guru Pembimbing Khusus di Sekolah Inklusi

Penyelenggaraan sekolah inklusi harus dilengkapi dengan guru pembimbing khusus (GPK). ${ }^{14}$ GPK adalah guru yang mempunyai tanggung jawab besar dalam keberlangsungan pelaksanaan pendidikan inklusi. Dalam buku pendoman pelaksanaan sekolah inklusi disebutkan bahwa GPK harus mempunyai kompetensi sebagai guru yang lain yang meliputi pedagogik, kepribadian, profesional, dan sosial. Namun secara khusus, GPK juga harus mempunyai tiga kompetensi khusus yang meiputi: (1) kompetensi umum (general ability) yaitu merupakan kemampuan guru yang berkaitan dengan kecakapan untuk mendidik siswa secara umum (anak normal), (2) kompetensi dasar (basic ability) yaitu kompetensi yang berkaitan dengan kecakapan untuk mendidik siswa yang memiliki kebutuhan khusus, dan (3) kompetensi khusus (specific ability) yaitu kompetensi yang berkaitan dengan kecakapan untuk mendidik siswa yang mempunyai kebutuhan khusus tertentu (spesialis). Dengan demikian maka seorang GPK harus memiliki kompetensi khusus yang dibutuhkan untuk melaksanakan tugas membimbing anak berkebutuhan khusus dan tidak hanya memerlukan empat kemampuan guru secara umum.

Peran strategis GPK di sekolah inklusi tentunya sulit untuk digantikan oleh guru umum (guru mata pelajaran). Guru pembimbing khusus mempunyai tugas ikut anddil dalam: (1) Membuat instrumen asesmen siswa yang dibutuhkan oleh satuan pendidikan dalam penerimaan siswa dan bersama dengan guru mata pelajaran dan guru dalam menyusun instrumen penilaian, (2) Membuat sistem untuk mempermudah dalam koordinasi antara guru atau sekolah dengan orang tua siswa, (3) Melakukan pendampingan terhadap ABK dalam kegiatan pembelajaran baik pada saat ABK belajar bersama anak normal dengan guru bidang studi atau pelajaran bersama dengan guru kelas ataupun ABK pada saat belajar diruang tersendiri (4) Memberi layanan khusus atau bantuan bagi ABK pada saat mereka mengalami kesulitan dan hambatan ketika melakukan kegiatan belajar di kelas reguler, misalnya dapat berbentuk remidial atau pengayaan, (5) Mlaksanakan bimbingan secara terus menerus serta menyiapkan catatan khusus bagi ABK pada saat mereka melaksanakan

${ }^{13}$ Syafrida Elisa and Aryani Tri Wrastari, "Sikap guru terhadap pendidikan inklusi ditinjau dari faktor pembentuk sikap," Jurnal Psikologi Perkembangan dan Pendidikan 2, no. 01 (February 2013): 110.

14 Direktorat PPK-LK Pendidikan Dasar, Pedoman Umum Pendidikan Inklusif (Jakarta: Kementerian Pendidikan dan Kebudayaan, 2011). 
kegiatan belajar, sehingga dapat memberikan gambaran perkembangan yang mudah dipahami pada saat dilakukan pergantian guru, (6) Berbagi pengalaman kepada semua guru mata pelajaran dan guru kelas di sekolah tersebut, sehingga mereka dapat melakukan hal yang sama dalam memberi pelayanan dalam aktivitas pendidikan kepada ABK.

Dari paparan diatas sangatlah jelas bahwa GPK harus memahami secara utuh dan mendalam tugas dan fungsinya saat melaksanakan tuganya di satuan pendidikan. GPK mempunyai tugas yang sangat mulia dan strategis yang keberadaannya tidak dapat digantikan. GPK bersama dengan guru yang lain harus mahu membahu untuk memberikan layanan pendidikan yang maksimal kepada anak ABK. Untuk memenuhi keberadaan GPK di sekolah inklusi, maka ada tiga carayang dapat dilakukan oleh satua pendidikan inklusi. Tiga mekasnisme tersebut adalah: pertama, sekolah inklusi melakukan kerjasama dengan guru Sekolah Luar Biasa yang terdekat; kedua, sekolah inklusi melakukan rekruitmen GPK dengan kualifikasi berpendidikan Luar Biasa. Sekolah inklusi juga dapat melakukan pelatihan tentang ABK terhadap guru reguler, dan ketiga, sekolah inklusi melakukan klinik-klinik pendidikan dengan bekerja sama seperti dengan pusat pengembangan anak. Melalui program ini guru umum di sekolah inklusi akan memperoleh keterampilan dan beragam kualifikasi penangan anak berkebutuhan khusus sehingga dapat kompeten menjadi GPK. Dengan dihasilkannya GPK melalui pendidikan dan klinik-klinik pendidikan yang bermacam-macam itu, peran dan tugas GPK di sekolah inklusi dapat berjalan dengan baik dan optimal.

Untuk menyelenggarakan sekolah inklusi, satuan pendidikan harus mendapat persetujuan pemerintah. Hal ini adalah untuk memastikan bahwa pelaksanaan pendidikan inklusi tersebut berjalan dengan baik. Sekolah inklusi harus melaksanakan kurikulum yang bersifat fleksibel. Fleksibelitas kurikulum ini adalah dengan cara menyesuaikan kurikulum yang akan diterapkan dengan kebutuhan setiap siswa-siswinya. Pada pelaksanaan pembelajran di sekolah inklusi sangat memungkinkan untuk melakukan diferensiasi pembelajaran. Diferensiasi pembelajaran maksudnya adalah melakukan penyederhanaan baik pada aspek metode pembelajaran maupun materi pembelajaran. Dalam pelaksanaan semua itu sangat memerlukan uluran tangan dari GPK. GPK adalah guru yang mempunyai tugas untuk melakukan desain semua ini. 


\section{Guru Pendidikan Agama Islam di Sekolah Inklusi}

Guru Pendidikan Agama islam di sekolah inklusi mempunyai tugas yang sama dan bahkan lebih berat dari guru PAI di sekolah umum. ${ }^{15}$ Untuk mendukung pelaksanaan tugas sebagai pendidik di sekolah, maka guru PAI harus profesional, mempunyai kompetensi dan kecakapan yang mumpuni. Profesionalistas guru sangat berpengaruh terhadap keberhasilan sebuah pendidikan. Standar komptensi guru profesional yang yang ditetapkan meliputi:

a. Kompetensi Pedagogik merupakan kompetensi yang berkaitan dengan peserta didik, melakukan perancangan dan pelaksanaan proses pembelajaran, serta melakukan evaluasi hasil belajar. Kompetensi ini juga berkaitan dengan pengembangan peserta didik agar dapat mengembangkan berbagai potensinya secara optimal. Sub kompetensi Pedagogik meliputi:

1) Kemampuan memahami peserta didik secara menyeluruh sehingga dapat memamfaatkan teori-teori perkembangan menurut psikologi kognitif, psikologi kepribadian, dan mengasesment kebutuhan peserta didik.

2) Kemampuan merancang pembelajaran yang meliputi pemahaman landasan pendidikan, diimplementasikan dalam menerapkan teori-teori belajar, menetapkan strategi pembelajaran yang akan diterapkan yang disesuaikan dengan karakteristik siswa, tujuan yang akan dicapai, dan materi pembelajaran, serta dapat menyusun rancana pelaksanaan pembelajaran.

3) Mampu melaksanakan pembelajaran dengan melakukan penataan latar (setting) pembelajaran sehingga pelaksanakan pembelajaran dapat berjalan dengan kondusif.

4) Mampu merancang serta melaksanakan evaluasi (assessment) dalam proses pembelajaran, sehingga dapat dijadikan bahan evaluasi diri dalam proses pembelajaran yang berkesinambungan. Hal ini digunakan untuk menganalisis apakah proses pembelajaran yang meliputi strategi, metode, alat dan hasil belajar telah sesuai dengan keinginan atau belum. Evaluasi ini juga untuk menentukan tingkat ketuntasan belajar (mastery level) sehinggadapat dilakukan perbaikan proses pembelajaran sehingga diperoleh pembelajaran yang ber kualitas secara umum.

15 Sutipyo Ru'iya, Hanif Cahyo Adi Kistoro, and Sutarman, "Educating with Paying Attention to Individual Differences: Case Study of Slow Learner Students in Inclusion School:" (1st Paris Van Java International Seminar on Health, Economics, Social Science and Humanities (PVJ-ISHESSH 2020), Bandung, West Java, Indonesia, 2021), https://doi.org/10.2991/assehr.k.210304.026. 
5) Mampu mengembangkan siswa untuk meningkatkan berbagai potensinya, dengan cara memberi beberapa fasilitas kepada siswa dalam proses pengembangan potensi akademik, dan memberi fasilitas kepada siswa untuk melakukan pengembangan diri dalam potensi nonakademiknya.

b. Kompetensi Kepribadian merupakan kompetensi yang harus dimiliki setiap person sehingga mencerminkan pribadi yang mantap, dewasa, stabil, bijaksana dan berwibawa. Seorang guru layak untuk diteladani oleh seua peserta didik, dan seorang guru harus berakhlak mulia. Sub kompetensi kepribadian ini meliputi beberapa hal, antara lain:

1) Kepribadian yang mantap dan stabil. Seorang guru harus dapat berperilaku sesuai dengan nilai-nilai norma sosial yang berlaku, seorang guru juga bangga dengan profesinya sehingga memiliki tanggung jawab dan selalu konsisten terhadap norma sosial masyarakat dalam bertindak.

2) Kepribadian yang dewasa. Seorang guru harus dapat berpenampilan yang bersahaja, mandiri dan bertanggung jawab dalam setiap tindak tanduknya, dan memiliki etos kerja tang tinggi sebagai guru.

3) Kepribadian yang arif. Seorang guru harus dapat memberikan kemamfaatan peserta didik dalam setiap tindakannya, bertanggung jawab pada institusi (sekolah) dan masyarakat serta menunjukkan sifat keterbukaan dalam bertindak.

4) Kepribadian yang berwibawa. Seorang guru harus memiliki berpengaruh yang positif terhadap seluruh aspek kehidupan peserta didik, sehingga guru tersebut disegani oleh siswa dan orang lain.

5) Berakhlak mulia. Seorang guru harus dapat menjadi teladan dalam setiap tindakannya, karena seluruh tindakannya sesuai dengan norma religius yang meliputi iman dan taqwa, jujur, ikhlas, dansuka menolong. Perilaku-perilaku religius ini akan diteladani oleh peserta didik dalam setiap sudut kehidupannya.

c. Kompetensi Profesional merupakan kompetensi yang harus dimiliki berupa penguasaan terhadap materi pembelajaran secara benar dan mendalam. Penguasaan materi ini meliputi penguasaan materi dalam kurikulum mata pelajaran di sekolah secara substansional dalam rumpun keilmuan yang menaunginya. Seorang guru juga harus dapat menguasai seluruh struktur dan metodologi keilmuannya secara luas dan mendalam. Sub kompetensi Profesional ini meliputi: 
1) Guru harus menguasai semua materi, baik berupa struktur atau konsep maupun pola pikir keilmuan serta hal-hal mendukung seluruh pelajaran yang dimampu.

2) Guru harus memahami standar kompentensi serta kompetensi dasar pada mata pelajaran/bidang yang dimampu. Guru juga harus dapat mengembangkan kompetensi tersebut ke dalam indikator-indikator capaian yang harus dikuasi oleh siswa.

3) Guru harus secara kreatif dapat mengembangkan materi pelajaran yang dimampu sehingga mudah dipahami oleh siswa.

4) Guru harus dapat melakukan tindakan reflektif secara berkelanjutan untuk mengembangkan keprofesionalannya.

5) Guru harus dapat memanfaatkan Teknologi Informasi dan Komunikasi dalam proses pembelajaran sehingga dapat berkomunikasi dengan lacar baik dengan siswa maupun dengan orangtua siswa serta memanfaatkannya dalam pengembangan diri guru tersebut.

d. Kompetensi Sosial merupakan kompetensi guru yang berupa kemampuan dalam berkomunikasi dan bergaul dengan efektif terhadap sesama tenaga kependidikan, peserta didik, orang tua/wali peserta didik, dan masyarakat. Sub kompetensi Sosial ini meliputi:

1) Guru harus mempunyai sikap inklusif, yaitu seorang guru harus bertindak secara obyektif dan tidak diskriminatif kepada peserta didik baik karena jenis kelamin, latar belakang keluarga, status sosial, atau karena agama, ras, terlebih-lebih karena kondisi fisik mereka.

2) Guru harus mampu berkomunikasi secara efektif, baik dengan sesama pendidik, dengan tenaga kependidikan, ataupun dengan orang tua dan masyarakat. Dengan demikian guru tersebut akan dikenal sebagai orang empatik dan santun.

3) Guru harus mampu beradaptasi di tempat bertugas baru dimana saja dia ditempatkan di seluruh wilayah Republik Indonesia dengan berbagai keragaman budayanya.

4) Guru harus mampu berkomunikasi dengan baik secara lisan maupun tulisan.

Secara lebih singkat menurut Boulter et al. ada lima dimensi komptensi yang harus dimiliki profesional termasuk oleh guru, ${ }^{16}$ yaitu:

16 Anastasia Lisa Bintari and Budiono, "Pengaruh Kompetensi Dan Pengembangan Karir Terhadap Kinerja Karyawan Pada Pt Purnama Indonesiasidoarjo” 6, no. 4 (2018): 520-629. 
a. Task skills, adalah kemampuan yang diperlukan untuk melakukan tugas-tugas rutin yang berada di tempat kerja dan harus sesuai dengan standar patokan yang ada.

b. Task management skills, adalah kemampuan dalam mengelola yang beraneka macam tugas yang dibebankan dalam suatu pekerjaan.

c. Contigency management skills, adalah kemampuan dan keterampilan bertindak dan mengambil keputusan secara cepat dan tepat pada saat dihadapkan pada masalah pada proses pelaksnaan pekerjaan.

d. Job role environment skills, adalah kemampuan untuk dapat bekerja sama dan menciptakan suasana yang kenyamanan dalam lingkungan kerja.

e. Transfer skill, adalah kemampuan untuk melakukan adaptasi terhadap lingkungan kerja yang baru.

Komptensi-kompetensi di atas adalah kompetensi guru secara umum. Adapun guru yang mengajar pada sekolah inklusi harus memiliki standar yang lebih dari standar guru secara umum sebagaimana di atas. Guru yang mengajar pada sekolah inklusi harus memupunyai beberapa kemampuan tanbahan diantaranya:

a. Mempunyai pengetahuan yang berkaitan dengan perkembangan ABK, hal ini dapat diperdalam oleh seorang guru melalui psikologi anak luar biasa.

b. Menyadari akan pentingnya mendorongan dan penghargaan kepada semua anak berkenaan dengan berbagai aspek perkembangannya. Memberi motivasi dalam setiap proses belajar dengan berinteraksi positif dan tidak menyimpang dari sumber belajar.

c. Mempunyai pemahaman akan pentingnya hak-hak anak yang diimplementasikan dalam proses pendidikan sehingga semua anak dapat berkembang secara maksimal.

d. Mempunyai pemahaman akan pentingnya untuk mewujudkan lingkungan yang ramah dalam pembelajaran yang diimplementasikan dalam wujud isi atau bahan pembelajaran dan dalam hubungan sosial.

e. Mempunyai pemahaman bahwa belajar aktif itu sangat penting karena akan dapat mengembangkan pemikiran anak yang kreatif dan logis.

f. Mempunyai pemahaman akan pentingnya evaluasi serta asssesmen yang dilakukan secara berkesinambungan oleh guru dalam proses pendidikan.

g. Mempunyai pemahaman tentang konsep pendidikan inklusi dan tata cara pelaksanaan sekolah inklusi sehingga dapat meaksanakan pembelajaran yang berdeferensiasi. 
h. Mempunyai pemahaman yang benar tentang hambatan belajar bagi anak termasuk yang disebabkan oleh karena faktor psikologis/mental dan juga fisik.

i. Mempunyai pemahaman konsep pendidikan yang berkualitas sehingga dapat mengimplementasikan pendekatan dan metode baru dalam proses pendidikan inklusi. ${ }^{17}$

\section{Tantangan Pelaksanaan Sekolah Inklusi}

Sekolah inklusi di Indonesia telah berjalan beberapa tahun terakhir ini dan pemerintah mempunyai perhatian cukup besar terhadap kebijakan sekolah inklusi. Akan tetapi pada realitas di lapangan, penyelenggaraan sekolah inklusi belum secara merata berjalan dengan baik. Ada beberapa tantangan yang harus dihadapi dari penyelenggaraan sekolah inklusi:

a. Guru, yaitu ketersediaan guru pendamping khusus (GPK) belum merata. Demikian juga dengan kompetensi guru yang ada di sekolah banyak yang masih minim tentang ABK.

b. Orang tua, yaitu belum banyak kepedulian orang tua terhadap penanganan anak ABK,hal ini juga karena disebabkan karena pemahaman orangtua terhadap anak ABK masih minim.

c. Siswa, yaitu siswa yang mempunyai karakteristik berbeda seharusnya mendapat penangan yang berbeda juga, namun karena berbagai hal, sering penangan ABK disamakan dengan anak non-ABK.

d. Manajemen sekolah, yaitu manajemen sekolah inklusi masih belum ada perbedaan signifikan dengan sekolah biasa. Hal ini dimungkinkan karena pemahaman sekolah tentang sekolah inklusi juga masih kurang.

e. Masyarakat, yaitu masyarakat juga masih minim sekali dukungannya terhadap sekolah inklusi. ${ }^{18}$

\section{METODE PENELITIAN}

Penelitian ini merupakan penelitian lapangan dengan pendekatan kulitatif. Adapun lokasi penelitian ini adalah dari dua sekolah inklusi, yaitu sekolah A yang berlokasi di Kota Madya Yogyakarta dan sekolah B di yang berlokasi di Kabupaten Sleman. Subyek penelitian terdiri dari tiga orang guru Pendidikan Agama Islam dari sekolah tersebut, dengan jumlah di sekolah A terdapat dua orang guru Pendidikan

17 Praptiningrum, "Fenomena Penyelenggaraan Pendidikan Inklusif Bagi Anak Berkebutuhan Khusus."

18 Tarnoto, "Permasalahan-permasalahan yang dihadapi sekolah penyelenggara pendidikan inklusi pada tingkat SD." 
Agama Islam dan dan satu orang GPK, sedangkan di sekolah B terdapat tiga orang guru Pendidikan Agama Islam. Pengumpulan data yang dilakukan pada penelitian ini melalui wawancara mendalam (deep interview) kepada semua guru Pendidikan Agama Islam dan kepada Guru Pembimbing Khusus (GPK) dari sekolah A.

Setelah data dikumpulkan selanjutkan dilakukan reduksi data yaitu suatu langkah berpikir kritis untuk menggolongkan, mengarahkan, membuang data yang tidak perlu dan mengorganisasi data sedemikian rupa sehingga mengarah kepada kesimpulan akhir. Tahapan berikutnya adalah penyajian atau penyusunan data sehingga memberi gambaran jelas yang berupa teks naratif. Tahap terakhir adalah penarikan kesimpulan yang merupakan temuan terbaru yang berupa deskripsi atau gambaran sesuatu objek yang sebelumnya masih belum jelas, sehingga setelah diteliti dan melalui tahapan-tahapan tertentu sehingga data menjadi jelas. ${ }^{19}$

\section{HASIL DAN PEMBAHASAN}

Dari data yang diperoleh dalam penelitian, setelah melalui analisis kualitatif sebagaimana tahapan-tahapan yang disampaikan Miles dan Huberman, maka dihasilkan beberapa point berikut ini:

1. Guru PAI belum mempunyai kompetensi khusus

Keempat guru PAI yang mengajar di sekolah inklusi baik di sekolah A maupun di sekolah $\mathrm{B}$, tidak mempunyai latar belakang pendidikan khusus untuk menangangi anak berkebutuhan khusus. "Saya lulusan UIN dan dulu ketika kuliah tidak ada mata kuliah yang berkaitan dengan anak berkebutuhan khusus" kata Ibu Ani (nama samaran) dari sekolah A. Hal yang sama juga disampaikan oleh Bapak Tono dari sekolah A, dan Bapak Kholili, serta Ibu Sri dari sekolah B (semua nama samaran). Lain halnya dengan Ibu Supri dari sekolah B yang pernah mendapat mata kuliah PAI untuk sekolah inklusi, yang mengakatan: "Saya bersyukur dulu pernah belajar inklusi, walau hanya sedikit."

Kenyataan ini sangat berbeda dengan idealisme pelaksanaan sekolah inklusi yang seharusnya semua guru yang mengajar di sekolah tersebut harus pernah mempelajari tentang anak berkebutuhan khusus. Sebagaimana yang dikatakan Praptiningrum, ${ }^{20}$ bahwa seharusnya guru yang berada pada sekolah inklusi harus memiliki standar yang lebih dari standar guru secara

19 Matthew B. Miles and A. Michael Huberman, Analisis Data Kualitatif: Buku Sumber Tentang Metode-Metode Baru (Jakarta: UI-Press, 1992). Khusus."

20 Praptiningrum, "Fenomena Penyelenggaraan Pendidikan Inklusif Bagi Anak Berkebutuhan 
umum sebagaimana di atas. Guru yang mengajar pada sekolah inklusi harus memupunyai beberapa kemampuan tanbahan diantaranya:

a. Pengetahuan tentang perkembangan anak berkebutuhan khusus, hal ini dapat diperdalam oleh seorang guru melalui psikologi anak luar biasa.

b. Pemahaman akan pentingnya mendorong rasa penghargaan kepada anak berkaitan dengan perkembangan, motivasi dan belajar melalui interaksi positif dan berorientasi pada sumber belajar.

c. Pemahaan tentang konvensi hak-hak anak dan implikasinya terhadap implementasi pendidikan dan perkembangan semua anak.

d. Pemahaman tentang pentingnya menciptakan lingkungan yag ramah terhadap pembelajaran yang berkaitan dengan isi, hubungan sosial, pendekatan dan bahan pembelajaran.

e. Pemahaman akan pentingnya belajar aktif dan pengembangan pemikiran kreatif dan logis.

f. Pentingnya pemahaman tentang evaluasi dan asssesmen yang berkesinambungan oleh guru yang bersangkutan

g. Pemahaman konsep inklusi dan pengayaan serta tata cara pelaksanaan inklusi dan pembelajaran yang berdeferensiasi.

h. Pemahaman terhadap hambatan belajar terasuk yang disebabkan oleh hambatan psikologis/mental dan fisik.

i. Pemahaman konsep pendidikan berkualitas dan kebutuhan implementasi pendekatan dan metode baru.

2. Guru PAI Kesulitan memahami karakteristik ABK

Anak berkebutuhan khusus mempunyai karakteristik berbeda dengan anak normal. Salah satu contohnya di kedua sekolah, ABK yang ada adalah anak slow learner yang mempunyai kelambatan atau kekurangan secara kognitif. Belum lagi anak slow learner banyak yang hiperaktif dan ada juga yang autis. Kedua karakter ABK ini sangat berbeda dengan anak normal, sehingga memerlukan penangan khusus dalam belajar.

Dalam kamus APA didefinisikan bahwa slow learner adalah anak dengan kecerdasan di bawah rata-rata ${ }^{21}$ Istilah lain dari siswa yang lambat belajar antara lain keterbelakangan mental,22 gangguan kognitif ringan,

21 Gary R. VandenBos, APA Dictionary of Psychology (Washington DC: American Psychological Association, 2007).

${ }^{22}$ Eman Gaad, Inclusive Education in the Middle East (New York: Routledge, 2011). 
ketidakmampuan belajar secara umum. ${ }^{23}$ Definisi lain adalah belajar anak yang lambat adalah anak yang tidak berhasil dalam belajar karena minimum secara psikologis dan kemampuan kognitifnya. Slow learner adalah siswa yang lambat belajar, sehingga membutuhkan waktu yang lebih lama jika dibandingkan dengan siswa lain yang memiliki intelektual yang normal. ${ }^{24}$ Anak lamban belajar (slow learner) merupakan anak yang memiliki potensi intelektual sedikit di bawah normal, tetapi tidak termasuk anak tuna grahita. ${ }^{25}$ Sementara Cauhan mengatakan bahwa anak slow learner adalah anak yang sangat terbelakang dalam mata pelajaran dasar sehingga mereka membutuhkan bantuan khusus. ${ }^{26}$ Dari beberapa definisi yang telah disampaikan maka jelas bahwa anak slow learner adalah anak yang mempunyai kemampuan kognitif lebih rendah dari pada anak normal, sehingga akan membutuhkan waktu lebih lama untuk memahami pelajaran tertentu jika mereka diperlakukan sama seperti anak normal. Akan tetapi anak slow learner tidak termasuk pada kategori tuna grahita. Oleh karena itu, agar anak slow learner dapat mengikuti pelajaran sebagaimana anak normal dibutuhkan bantuan atau treatmen khusus.

Dari sisi kecerdasan yang presentasikan melalui alat ukur IQ, biasanya anak slow learner memiliki IQ antara 70-85.27 Peatling mengatakan bahwa anak slow learner dibagi lagi menjadi dua kelompok: terbelakang (yaitu, mereka yang memiliki skor tes kecerdasan dari 67 hingga 89) dan sub-normal (yaitu, mereka yang memiliki skor tes kecerdasan dari 90 hingga 100). ${ }^{28}$ Anakanak slow learner biasanya memiliki memiliki rentang IQ 70-90. ${ }^{29}$ Chauhan mengutip pendapat Jenson (1980) yang mengakatan juga bahwa rentang IQ anak slow learner bara pada kisaran $80-80 .^{30}$

23 Endry Boeriswati, "Peers' Instructional Interactions in Inclusive Classrooms: Slow Learner Students and Typical Students," International Journal of Multidisciplinary and Current Research 2, no. 1 (2017): 904-11.

24 Wachyu Amelia, "Karakteristik dan Jenis Kesulitan Belajar Anak Slow Learner," Jurnal Aisyah : Jurnal Ilmu Kesehatan 1, no. 2 (December 4, 2016): 53-58, https://doi.org/10.30604/jika.v1i2.21.

25 Fida Rahmantika Hadi, "Proses Pembelajaran Matematika Pada Anak Slow Learners (Lamban Belajar)," Premiere Educandum 6, no. 1 (2016): 36-41.

${ }^{26}$ Sangeeta Chauhan, "Slow Learners: Their Psychology And Educational Programmes," ZENITH: International Journal of Multidisciplinary Research 1, no. 8 (2011): 279-89.

27 Kathleen S. Cooter and Robert B. Cooter, “Issues in Urban Literacy: One Size Doesn't Fit All: Slow Learners in the Reading Classroom," The Reading Teacher 57, no. 4 (2014): 680-84.

28 John H. Peatling, "The Slow Learner and Religious Education: A Research Note," Learning for Living 14, no. 3 (January 1975): 102-6, https://doi.org/10.1080/00239707508557752.

29 Boeriswati, “Peers' Instructional Interactions in Inclusive Classrooms: Slow Learner Students and Typical Students."

${ }^{30}$ Chauhan, "Slow Learners: Their Psychology And Educational Programmes." 
Anak slow learner mempunyai karakteristik khas yang bebeda dengan anak normal. Salah satu ciri yang mencolok adalah mereka kesulitan dalam memahami pelajaran terutama yang bersifat abstrak. Anak slow learner biasanya tidak mampu mengatasi pekerjaan yang biasanya diharapkan dari kelompok usia mereka. Anak slow learner juga memiliki masalah dalam komunikasi, memiliki emosi yang kurang stabil, sulit dalam bersosialisasi. Oleh karena itu, bagi anak yang mempunyai kesulitan berat dalam emosi dan bersosialisasi harus di tempatkan pada kelas khusus karena membutuhkan terapi khusus. ${ }^{31}$ Namun bagi mereka yang tidak menunjukkan gejala nyata ketidakmampuan sosial, dan emosional dan biasanya ditempatkan di kelas reguler. ${ }^{32}$

Chauhan membagi penanganan anak slow learner menjadi dua yaitu: a) Anak-Anak yang membutuhkan penangan secara terpisah. Anak-anak ini biasanya ada tambahan kekhasan yang lebih parah, keterbelakangan dalam pendidikan yang disebabkan karena kerbelakangan mental dan beberapa kekurangan sosio-psikologis lainnya. Mereka membutuhkan lebih banyak perhatian dan ketentuan untuk sekolah, sehingga membutuhkan bentuk sekolah khusus atau kelas khusus. b) Anak-anak yang dapat ditangi dalam pendidikan secara terintegrasi. Sifat dan tingkat keparahan keterbelakangan belajar dan keterbelakangan akademik pada anak-anak ini tidak terlalu parah, sehingga pendidikannya dapat dilakukan bersama siswa yang umum dan terpadu sekolah yang ada (inklusi). Keterbelakangan mereka umumnya dua jenis - umum dan spesifik. Anak yang menderita keterbelakangan umum lemah dalam semua mata pelajaran kurikulum sekolah. Anak yang menderita keterbelakangan spesifik, di sisi lain, tertinggal dalam satu atau dua mata pelajaran khusus saja, sementara di orang lain kemajuannya mungkin memuaskan atau bahkan luar biasa. ${ }^{33}$

3. Ada Sekolah yang Belum Mempunyai Guru Pendamping khusus (GPK)

Pada sekolah A terdapat guru pendamping khusus (GPK), namun di sekolah B tidak mempunyai GPK. Hal ini membuat kesulitan bagi guru-guru yang mengajar di sekolah B dalam menangangi anak berkebutuhan Khusus. Hal ini sesuai dengan hasil penelitian Tarnoto yang menghasilkan beberapa

31 Mohsen Shokoohi-Yekta, Nayereh Zamani, and Ahmad Ahmadi, "Anger Management Training for Mothers of Mildly Mentally Retarded and Slow Learner Children: Effects on Mother-Child Relationship," Procedia - Social and Behavioral Sciences 15 (2011): 722-26, https://doi.org/10.1016/j.sbspro.2011.03.172.

32 VandenBos, APA Dictionary of Psychology.

${ }^{33}$ Chauhan, "Slow Learners: Their Psychology And Educational Programmes." 
kendala dalam sekolah inklusi yang diantaranya adalah tidak mempunyai GPK. ${ }^{34}$

Untuk sekolah A para guru PAI dapat saling belajar dengan GPK dalam menangangi anak berkebutuhan khusus. Guru PAI di sekolah A menggunakan sistem pengembangan diri dengan sistem kolegial. Seorang guru memang harus dapat beajar bersama dengan guru lain. Menurut Hargreaves mengidentifikasi dan mengembangkan pengembangan profesional guru menjadi empat fase: (1) fase pra-profesional, (2) fase profesional otonom, (3) fase profesional kolegial, dan (4) fase pasca-profesional atau fase postmodern. ${ }^{35}$ Dalam fase pra-profesional, mengajar dipandang memenuhi tuntutan manajerial, tetapi secara teknis sederhana. Prinsip dan parameter diperlakukan dengan akal sehat yang tidak perlu dipertanyakan. Seseorang belajar menjadi guru melalui program magang, dan sebagai guru dia harus ditingkatkan melalui uji coba individu. Pada fase ini, guru adalah amatir: mereka hanya perlu melakukan sesuai dengan arahan supervisor mereka yang lebih berpengetahuan.

Menurut Hargreaves, tahap pra-profesional terus menjadi dominan di banyak negara Asia Timur, bukan hanya karena kendala ukuran kelas dan faktor lain tetapi juga karena pentingnya konsepsi budaya dalam mengajar di sekolah dan keluarga. Keterikatan budaya sakral (Kong $\mathrm{Hu} \mathrm{Cu}$ ) masih merajalela di Asia Timur (Jepang, China, Thailand, Vietnam, Myanmar) dalam bentuk berbagai aktivitas sosial. Keterikatan yang kuat juga bisa diamati di bidang pendidikan. Hal ini problematis, karena keterikatan pada budaya sakral dapat menjadi salah satu faktor yang menghambat profesionalisme guru dalam proses belajar mengajar.

Fase profesional otonom dicirikan oleh singularitas pengajaran dan tradisi yang tidak diragukan lagi yang membentuknya. Pendidikan guru pra-jabatan di universitas dan pertumbuhan pendidikan dalam jabatan oleh para ahli menambah bobot pada klaim terhadap keahlian yang menjadi dasar hak otonomi. Meskipun demikian, manfaat pendidikan guru dalam masa jabatan jarang diintegrasikan ke dalam praktik di kelas, ketika masing-masing peserta kembali ke sekolah dan kepada rekan kerja yang tidak antusias, tidak mengerti, dan juga tidak berbagi pembelajaran dengan mereka. Akhirnya, pedagogi

34 Tarnoto, "Permasalahan-permasalahan yang dihadapi sekolah penyelenggara pendidikan inklusi pada tingkat SD."

35 A. Hargreaves, "Four Ages of Professionalism and Professional Learning," Teachers and Teaching: History and Practice 6, no. 2 (n.d.): 151-82. 
sebagian besar mandek karena guru enggan atau tidak dapat menonjol dari rekan-rekan mereka dan membuat perubahan lebih dari yang mereka sendiri.

Dalam fase profesional kolegial, terdapat peningkatan upaya membangun budaya profesional kolaboratif yang kuat untuk mengembangkan tujuan bersama, mengatasi ketidakpastian dan kompleksitas, merespons secara efektif perubahan dan reformasi yang cepat, menciptakan iklim yang menghargai risiko yang diambil dan terus meningkatkannya, mengembangkan rasa efektivitas guru yang lebih kuat, dan menciptakan budaya pembelajaran profesional yang berkelanjutan bagi guru. Yang terakhir menggantikan pola pengembangan staf, yang bersifat individual, episodik, dan lemah dengan prioritas sekolah.

Fase pasca profesional terjadi pada pergantian milenium atau era postmodernisme. Nasib profesionalisme guru di era ini sama sekali tidak menentu, namun tetap eksis dan akan diperdebatkan, dilawan, dan ditarik ke berbagai arah di berbagai tempat pada waktu yang berbeda. Menurut Hargreaves, salah satu kemungkinan hasil dari proses ini adalah profesionalisme postmodern baru. Ini lebih luas, lebih fleksibel, dan lebih demokratis, termasuk kelompok di luar ajaran dan perhatian mereka dibandingkan dengan pendahulunya. Hargreaves menyatakan bahwa munculnya profesionalisme guru di era postmodern dibantu oleh gerakan sosial yang sadar akan mereka yang berkomitmen. Namun, banyak kepentingan di dalamnya mengarahkan guru untuk pengukuran rinci dan kerangka kerja pengendalian kompetensi yang diatur secara sempit, berdasarkan sektor perusahaan dan sistem administrasi oleh manajemen kinerja.

\section{KESIMPULAN}

Dari pembahasan yang telah dipaparkan pada bagian sebelumnya dapat disimpulkan bahwa problematika guru Pendidikan Agama Islam di sekolah A dan Sekolah B ada persamaan problem. Tema-tema tantangan yang dihadapi guru Pendidikan Agama Islam di sekolah inklusi tersebut diantaranya adalah:

a. Guru PAI yang mendapat tugas mengajar di kelas inklusi, belum pernah mendapat pendidikan secara khusus untuk menangani anak berkebutuhan khusus (ABK). Hal ini berimbas kepada minimnya kemampuan dalam pemahaman karakter ABK.

b. Kesulitan memahami karakteristik ABK yang berbeda dengan anak normal, misalnya anak slow learner atau anak yang belajar lambat, mulai dari yang 
ringat sampai berat. Mereka mempunyai karakter berbeda-beda, dan kadangkadang selain slow learner juga beberapa anak mempunyai kekhususan ganda seperti hiperaktif atau juga autis.

c. Tidak semua sekolah mempunyai Guru Pendamping Khusus (GPK).

d. Untuk meningkatkan kemampuan dalam mendidik anak ABK, guru Pendidikan Agama Islam berkolaborasi dengan GPK dan memperkaya diri dengan banyak membaca buku-buku psikologi anak berkebutuhan khusus secara mandiri meningkatkan kesabaran.

\section{DAFTAR PUSTAKA}

Amelia, Wachyu. "Karakteristik dan Jenis Kesulitan Belajar Anak Slow Learner." Jurnal Aisyah: Jurnal Ilmu Kesehatan 1, no. 2 (December 4, 2016): 53-58. https://doi.org/10.30604/jika.v1i2.21.

Anggriana, Tyas Martika, and Rischa Pramudia Trisnani. "Kompetensi guru pendamping siswa ABK di sekolah dasar." JURNAL KONSELING GUSJIGANG 2, no. 2 (September 20, 2016): 157-64. https://doi.org/10.24176/jkg.v2i2.702.

Baharun, Hasan, and Robiatul Awwaliyah. "Pendidikan inklusi bagi anak berkebutuhan khusus dalam perspektif epistemologi Islam." MODELING: Jurnal Program Studi PGMI 5, no. 1 (March 2018): 57-71.

Bangun, Sabaruddin Yunis. "Pengembangan Pengetahuan Anak Difabel Melalui Pendidikan Jasmani Olahraga dan Outbound." Journal Physical Education, Health and Recreation 1, no. 1 (October 16, 2016): 70-77. https://doi.org/10.24114/pjkr.v1i1.4777.

Bintari, Anastasia Lisa, and Budiono. "Pengaruh Kompetensi Dan Pengembangan Karir Terhadap Kinerja Karyawan Pada Pt Purnama Indonesiasidoarjo" 6, no. 4 (2018): 520-629.

Boeriswati, Endry. "Peers' Instructional Interactions in Inclusive Classrooms: Slow Learner Students and Typical Students." International Journal of Multidisciplinary and Current Research 2, no. 1 (2017): 904-11.

Chauhan, Sangeeta. "Slow Learners: Their Psychology And Educational Programmes." ZENITH: International Journal of Multidisciplinary Research 1, no. 8 (2011): 27989.

Cooter, Kathleen S., and Robert B. Cooter. “Issues in Urban Literacy: One Size Doesn't Fit All: Slow Learners in the Reading Classroom." The Reading Teacher 57, no. 4 (2014): 680-84.

Dewi, Nurul Kusuma. "Manfaat program pendidikan inklusi untuk AUD.” Jurnal Pendidikan Anak 6, no. 1 (2017): 12-19.

Direktorat PPK-LK Pendidikan Dasar. Pedoman Umum Pendidikan Inklusif. Jakarta: Kementerian Pendidikan dan Kebudayaan, 2011. 
Elisa, Syafrida, and Aryani Tri Wrastari. "Sikap guru terhadap pendidikan inklusi ditinjau dari faktor pembentuk sikap." Jurnal Psikologi Perkembangan dan Pendidikan 2, no. 01 (February 2013): 1-10.

Fernandes, Reno. "Adaptasi Sekolah Terhadap Kebijakan Pendidikan Inklusif." SOCIUS 4, no. 2 (March 12, 2018): 119-25. https://doi.org/10.24036/scs.v4i2.16.

Gaad, Eman. Inclusive Education in the Middle East. New York: Routledge, 2011.

Hadi, Fida Rahmantika. "Proses Pembelajaran Matematika Pada Anak Slow Learners (Lamban Belajar)." Premiere Educandum 6, no. 1 (2016): 36-41.

Hargreaves, A. "Four Ages of Professionalism and Professional Learning." Teachers and Teaching: History and Practice 6, no. 2 (n.d.): 151-82.

Miles, Matthew B., and A. Michael Huberman. Analisis Data Kualitatif: Buku Sumber Tentang Metode-Metode Baru. Jakarta: UI-Press, 1992.

Peatling, John H. "The Slow Learner and Religious Education: A Research Note." Learning for Living 14, no. 3 (January 1975): 102-6. https://doi.org/10.1080/00239707508557752.

Praptiningrum, N. "Fenomena Penyelenggaraan Pendidikan Inklusif Bagi Anak Berkebutuhan Khusus." Jurnal Pendidikan Khusus 7, no. 1 (2010): 32-38.

Pratiwi, Jamilah Candra. "Sekolah inklusi untuk anak berkebutuhan khusus: Tanggapan terhadap tantangan kedepannya." Prosiding Seminar Nasional Pendidikan, November 21, 2015, 237-42.

Ru'iya, Sutipyo, Hanif Cahyo Adi Kistoro, and Sutarman. "Educating with Paying Attention to Individual Differences: Case Study of Slow Learner Students in Inclusion School:" Bandung, West Java, Indonesia, 2021. https://doi.org/10.2991/assehr.k.210304.026.

Shokoohi-Yekta, Mohsen, Nayereh Zamani, and Ahmad Ahmadi. "Anger Management Training for Mothers of Mildly Mentally Retarded and Slow Learner Children: Effects on Mother-Child Relationship." Procedia - Social and Behavioral Sciences 15 (2011): 722-26. https://doi.org/10.1016/j.sbspro.2011.03.172.

Somantri, T. Sutjihati. Psikologi Anak Luar Biasa. Jakarta: Refika Aditama, 2012.

Tarnoto, Nissa. "Permasalahan-permasalahan yang dihadapi sekolah penyelenggara pendidikan inklusi pada tingkat SD." HUMANITAS 13, no. 1 (July 19, 2016): 5061. https://doi.org/10.26555/humanitas.v13i1.3843.

VandenBos, Gary R. APA Dictionary of Psychology. Washington DC: American Psychological Association, 2007.

Wati, Ery. "Manajemen pendidikan inklusi di Sekolah Dasar Negeri 32 Kota Banda Aceh." Jurnal Ilmiah Didaktika 14, no. 2 (February 1, 2014): 368-78. https://doi.org/10.22373/jid.v14i2.508.

Zakia, Dieni Laylatul. "Guru pembimbing khusus (GPK): Pilar pendidikan inklusi." Prosiding Seminar Nasional Pendidikan, November 21, 2015, 110-16. 